Nikola Davidović

Research engineer EDePro company, Belgrade

Predrag Miloš

Research engineer EDePro company, Belgrade

Aiman Elmahmodi

Associate professor University of Tripoli

Lybia

Marko Miloš

Associate professor University of Belgrade Faculty of Mechanical Engineering

Branislav Jojić

Professor

University of Belgrade

Faculty of Mechanical Engineering

Ivana Todić

Teaching Assistan University of Belgrade Faculty of Mechanical Engineering

\section{Modification of Existing Turboshaft Engine in Order to Operate on Synthetic Gas}

Synthetic gas is nowadays the co-product of procceses such as waste gasification and processing biomass, coal and other potentional fuels. Although its composition depends on previous process, synthetic gas is generally mixture of hydrogen, carbon-monoxide and methane in different ratios. The idea to use gases from waste as a fuel for gas-turbine generator producing electric energy is very attractive but also challenging. In this paper is presented modification of an existing turbo-shaft engine in order to be capable to operate with synthetic gas. Together with problems such as low heating value of the gas, different stochiometric ratio of gas and air compared to kerosene/air combination and high hydrogen contents, the engineering task was to do it with minimum number of changes. Problem is solved by adjusting existing airblast atomizers and experimentally verified.

Keywords: airblast atomizer, combustion chamber, stochiometric ratio, synthetic gas.

\section{INTRODUCTION}

Synthetic gas is nowadays a co-product of processes such as waste gasification and processing biomass, coal and other potentional fuels. Although its composition depends on previous process, synthetic gas is generally mixture of hydrogen, carbon-monoxide and methane in different ratios. If we produce some benefit from such gas, it is obvious that we get something from the waste. Gas-turbine generator set is a typical application for such gases, but also brings a lot of problems to be solved: first of all most of gas-turbines are designed to work with kerosene or similar liquid fuels. This means that thermodynamic cycle parameters, combustion chamber air distribution, atomizers, turbine cross sections and fuel installation were chosen according to certain liquid fuel. In this paper is presented a modification of existing turbo-shaft engine in order to work with synthetic gas.

The primary requirement was to minimize changes i.e. time and cost. The engine was selected according to mentioned problems: low pressure ratio and wide equivalence ratio combustion chamber. Changes were done in existing atomizers and engine was tested with simulating gas consisting of $50 / 50 \% \mathrm{CO}$ and $\mathrm{H}_{2}$ by the volume. Gas was supplied to engine from the tank under pressure of seven bars. Tests show excellent behavior and practically identical thermodynamic efficiency.

\section{ENGINE DESCRIPTION}

Engine designation is TM-40 developed by Laboratory

Received: January 2014, Accepted: March 2014

Correspondence to: Dr Marko Milos

Faculty of Mechanical Engineering,

Kraljice Marije 16, 11120 Belgrade 35, Serbia

E-mail: mmilos@mas.bg.ac.rs

doi:10.5937/fmet1402112D

(C) Faculty of Mechanical Engineering, Belgrade. All rights reserved for jet propulsion from the Faculty of Mechanical Engineering from Belgrade University [1]. It is turboshaft engine with radial compressor and turbine, and reverse flow annular combustion chamber with 12 air blast atomizers. The engine is capable to produce $40 \mathrm{~kW}$ of power while in existing system is connected to the generator rated for $15 \mathrm{~kW}$. Working fuel is kerosene, diesel or gasoline while engine was also successfully tested with various liquid fuels such as palm oil, waste oil or ethanol. Engine design speed is $46000 \mathrm{rpm}$, pressure ratio 2.75 and exit temperature 900K. Engine assembly is shown at figure 1 .

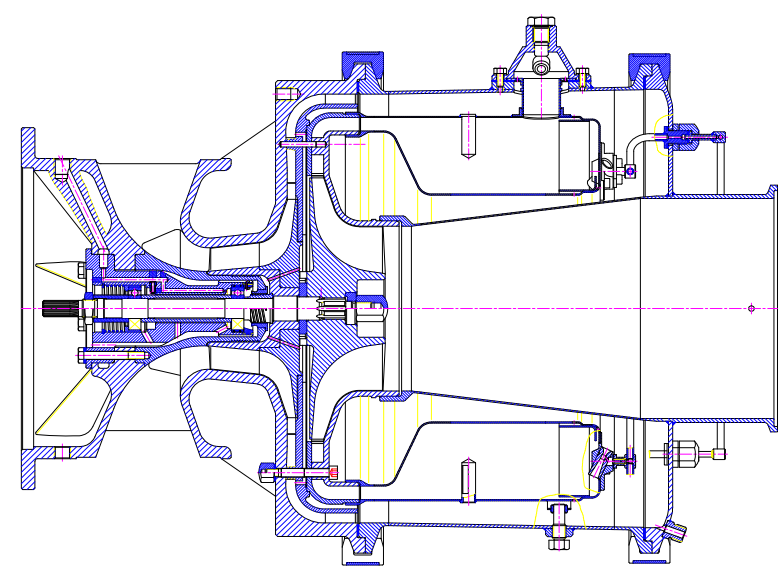

Figure 1.Engine assembly drawing

The engine system consists of the engine, fuel and oil installation, gear box, starter, generator and control unit. In order to simulate power consumption the system was loaded with three heaters with power of 2.5, 3.5, and $8 \mathrm{~kW}$ respectively. While liquid fuel is supplied with pump for synthetic gas operation, the engine is equipped with gas control valve. Gas control valve was made from existing pneumatic manual proportional valve and step motor with its own control, similar to [2]. It must 
be noted that it is very difficult to find such commercial valve capable to work with high hydrogen gas composition. The engine system is shown in figure 2 .

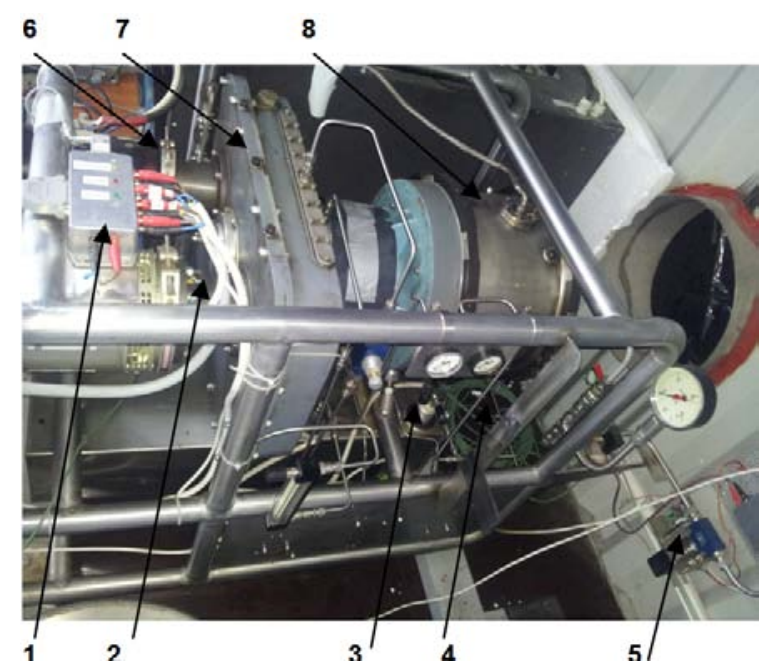

Figure 2.Engine system (1-control unit, 2-generator, 3-fuel pump and reservoir, 4-oil pump and reservoir, 5-syn-gas control valve, 6-starter, 7-gearbox, 8-engine)

\section{SYNTHETIC GAS PROPERTIES AND PROBLEMS RELATED TO USING IT AS A FUEL}

Synthetic gas is nowadays a co-product of procceses such as waste gasification and various industry waste gases. The logic idea is to use these gases as energy and to prevent atmospheric polution. To use such gases as a gas turbine fuel generally there are few problems:

-low heating value and different stochiometric ratio

-high contents of hydrogen

-gasesous fuel installation

-due to higher fuel flow rates, as a consenquence of lower heating value, total engine flow rate increases causing the compressor working point to be shifted toward surge line requiring modification of turbine stator passage.

The later disadvantage paradoxically would produce more power due to higher total engine flow rates [3].

Because the processes are different, it results in different composition i.e. properties of the gases, the so engine's performances may vary from plant to plant [4], [5]. Gas turbines are designed to work efficiently with kerosene and similar hydrocarbon liquid fuels so introducing fuel with lower heating value and completely different mixture ratio needs adjusting of existing system if possible. High contents of hydrogen cause dangerous handling fuel type. Finally, to introduce gas into the engine pressure should be more than inside combustion chamber i.e. synthetic gas must be pressurized. In most of existing gas turbines it is very difficult because of the high pressure ratio which is again used in the design to work efficiently with kerosene fuel types.

In this work synthetic gas composition is chosen according to the data from Pyromex facility in Munich:

$\mathrm{H}_{2}=48 \%$

$\mathrm{CO}=42 \%$

$\mathrm{CH}_{4}=2 \%$

\section{$\mathrm{C}_{2} \mathrm{H}_{6}=8 \%$}

All data are percentage by volume. Syngas comes from facility practically at atmospheric pressure and temperature. Further gas preparation for gas turbine should be connected to filtering and pressurizing and it was not considered in this investigation.

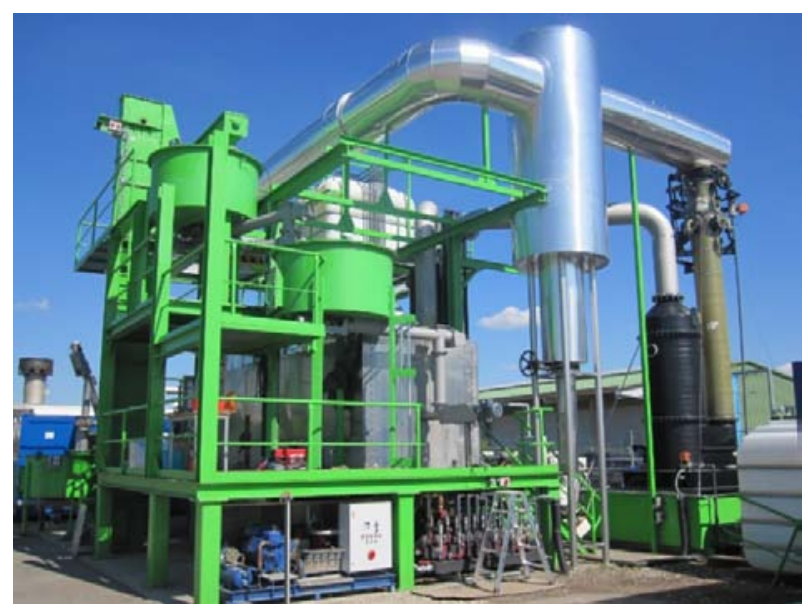

Figure 3. Pyromex facility in Munich

In order to simulate such gas, we simplified the composition to be:

$\mathrm{H}_{2}=50 \%$

$\mathrm{CO}=50 \%$

To calculate heating value and gas constant of such mixture first percentage by mass is calculated:

$$
\begin{gathered}
\rho_{H_{2}}=\frac{P \cdot V}{R_{u} / M_{H_{2}} \cdot T} \cdot 0.5=\frac{P \cdot V}{R_{u} \cdot T} \cdot 0.5 \cdot M_{H_{2}} \\
\rho_{C O}=\frac{P \cdot V}{R_{u} / M_{C O} \cdot T} \cdot 0.5=\frac{P \cdot V}{R_{u} \cdot T} \cdot 0.5 \cdot M_{C O}
\end{gathered}
$$

So

$$
\begin{aligned}
& P M_{\mathrm{H}_{2}}=\frac{\rho_{\mathrm{H}_{2}}}{\rho_{\mathrm{H}_{2}}+\rho_{\mathrm{CO}}}=\frac{M_{\mathrm{H}_{2}}}{M_{\mathrm{H}_{2}}+M_{\mathrm{CO}}}=0.0667 \\
& P M_{\mathrm{CO}}=\frac{\rho_{\mathrm{CO}}}{\rho_{\mathrm{H}_{2}}+\rho_{\mathrm{CO}}}=\frac{M_{\mathrm{CO}}}{M_{\mathrm{H}_{2}}+M_{\mathrm{CO}}}=0.9333
\end{aligned}
$$

Now heating value and gas constant are calculated:

$$
\begin{aligned}
& H_{m}=P M_{H_{2}} \cdot H_{H_{2}}+P M_{C O} \cdot H_{C O}=17.4 M J / k g \\
& R_{m}=P M_{H_{2}} \cdot R_{H_{2}}+P M_{C O} \cdot R_{C O}=554.4 \mathrm{~J} / \mathrm{kg} \cdot \mathrm{K}
\end{aligned}
$$

Compared to kerosene, this mixture has almost 2.5 times lower heating value which means that mass flow rate should be 2.5 times bigger to get the same energy. Also, because hydrogen mixture has a big gas constant i.e. approximately two times lower density compared to the air. Both of these conclusions lead to the requirement for big enough opening for gas injector. Several numerical and experimental investigation were done with synthetic gas of different compositions [6], [7], [8], [9] and [10] but this work deals with an engineering approach to adjust the engine. The mixture stochiometric ratio and burning temperature with air are 
calculating by using Combus software. Results are shown inthe graph below.

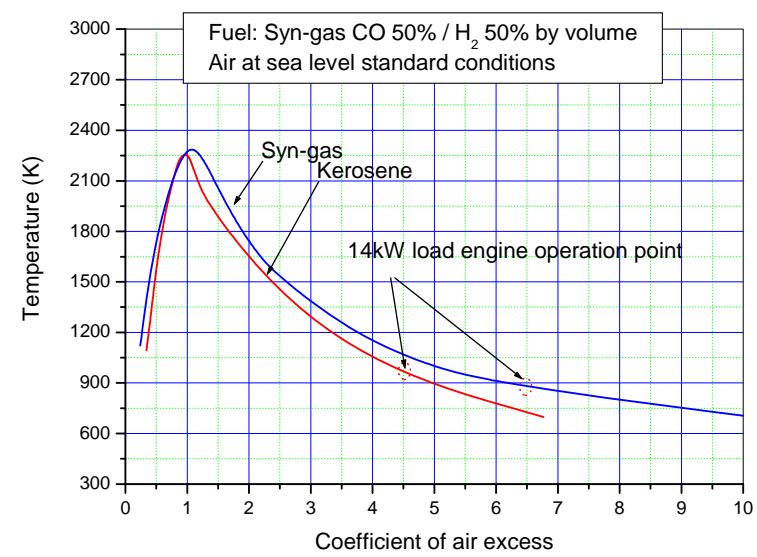

Figure 4.Combustion temperature vs. air to syn-gas/kerosene air excess coefficient

In this work was used the air excess coefficient as a measure of lean and rich mixture. While it is common in Russian literature, in Western literature more often equivalence ratio is used. There is simple direct connection: equivalence ratio is an inverse value of air excess coefficient.

In the figure 4 are also shown position of engine overall air excess coefficient with kerosene and syngas. Although temperatures with syngas are higher in existing combustion chamber mixture will always be leaner for 1.44 times, statement is described in more detail in the next paragraph.

\section{ORIGINAL AND MODIFIED ATOMIZER}

The original airblast atomizer is shown in the figure 5 . There are twelve atomizers, throat and exit diameter are 3 and $6.5 \mathrm{~mm}$ respectively. Fuel is injected in the throat at the angle of $60^{\circ}$ degrees upward to flow.

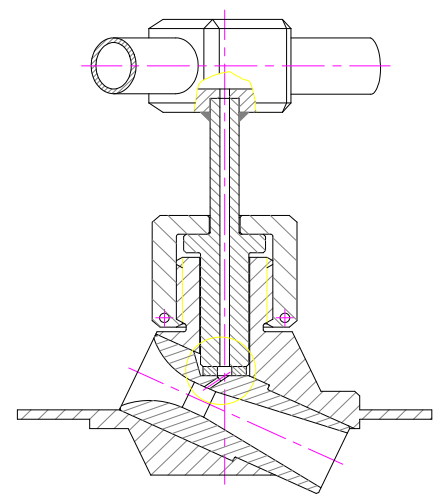

Figure 5. Original airblast atomizer assembly

This type of atomizer uses air kinetic energy to atomize fuel into fine droplets. There are twelve atomizers in engine combustion chamber arranged in tangential direction thus producing swirling flow and igniting each other i.e. producing stability. The atomizer is suitable for practically all known liquid fuels [11]. It was of primary importance not to change air excess coefficient in atomizer because of stability and ignition, having in mind importance of primary zone [12]. The original air distribution and combustion chamber are shown below [1].
Table 1. Combustion chamber original air distribution

\begin{tabular}{|c|c|}
\hline Atomizer air & $8.8 \%$ \\
\hline Film cooling slots air & $39.7 \%$ \\
\hline Dilution air & $51.5 \%$ \\
\hline \multicolumn{2}{|c|}{ front cooling slots air }
\end{tabular}

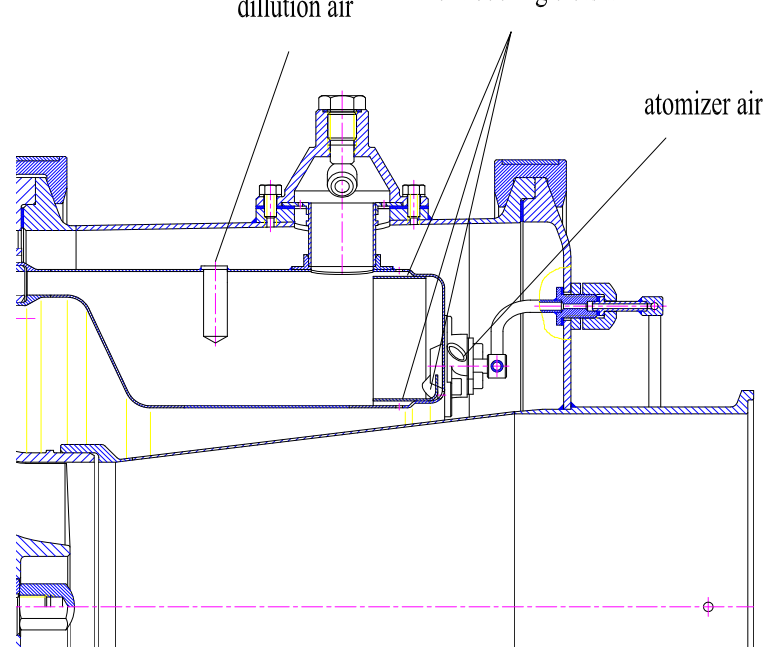

Figure 6. Combustion chamber air holes

\subsection{Atomizer air testing}

Required fuel flow rates as a function of engine power are shown in the figure 7 . Required kerosene flow is used from engine previous tests while syngas flow is calculated according to the heating value.

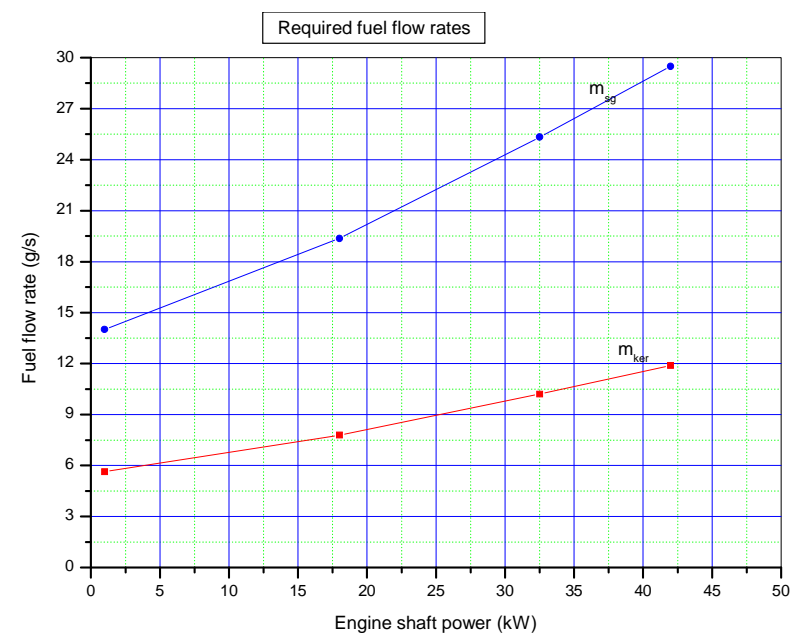

Figure 7. Engine required fuel flow rate for engine design speed of $46000 \mathrm{rpm}$

Modified airblast atomizers were tested with air, which means that both flows were simulated with laboratory air. It was done because syngas was not available at the moment of atomizer testing. This simplification is obviously causing difference compaed to real case with syngas due to its lower density but again giving enough engineering data. Atomizer air testing were performed with following procedure:

-air for airblast atomizer was supplied under constant gauge pressure simulating combustion chamber pressure drop.

-air substituting syn-gas was supplied independently through syn-gas pipe.

-both flows were measured through its own throat 
-position of gas pipe to atomizer inlet was measured with $\mathrm{x}=0$ and $\mathrm{x}=2.5 \mathrm{~mm}$.

Modified atomizer has a pipe of $2 \mathrm{~mm}$ diameter and a hole of $1.5 \mathrm{~mm}$ positioned axially at the inlet as shown in the figure 8.

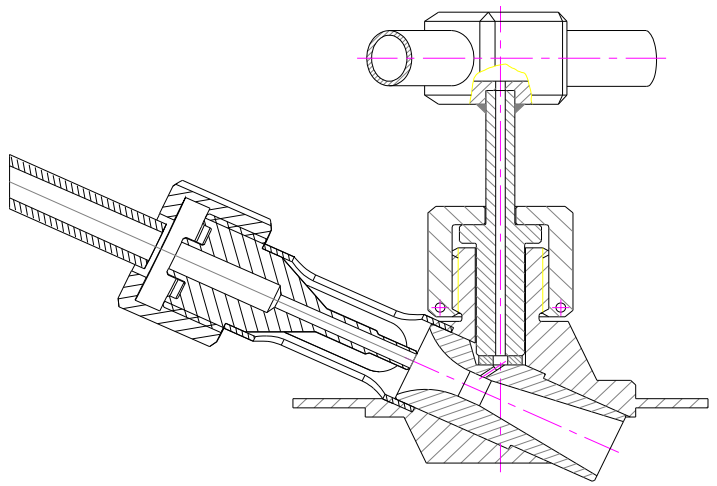

Figure 8. Modified airblast atomizer assembly

Modified atomizer test results are shown in the figure 9 .

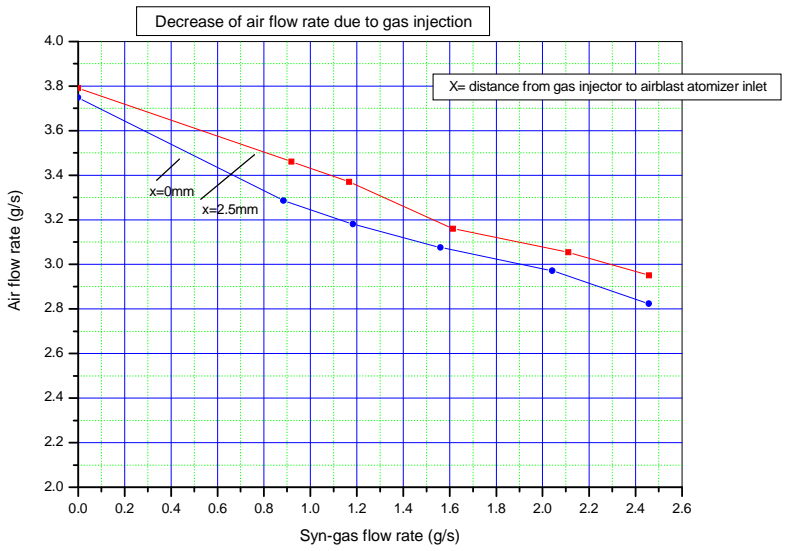

Figure 9. Decrease of air flow rate due to simulating gas injection

Although modification looks simple it has interesting views:

-Required syngas flow rate is 2.48 bigger than for kerosene according to heating values ratio.

-Stochiometric ratio of syngas to air is 0.28 comparing to kerosene.

-To have the same equivalence ratio in the atomizer, original air flow rate should be divided by 1.44 .

-Considering that gas injection would decrease air flow it was logic to assume that gas will maximum occupy section as it is at pipe exit if velocities are subsonic

-To decrease throat area by $44 \%$ gas diameter of $1.66 \mathrm{~mm}$ would be required. Diameter of $1.5 \mathrm{~mm}$ was chosen from production reason.

-In the regime when atomizer works simultaneously with liquid and gaseous fuel gas helps the liquid fuel atomization.

-The Combustion chamber equivalence ratio is 1.44 times leaner then with kerosene, but existing combustion chamber is already changing equivalence ratio more then double from idle to full engine power.

Finally the comparison of equivalence ratio of proposed injector using syn-gas and propane as fuel to original atomizer using kerosene is shown at the figure 10. Data for kerosene are used from known measured values, while for syn-gas and propane is calculated according to their heating values.

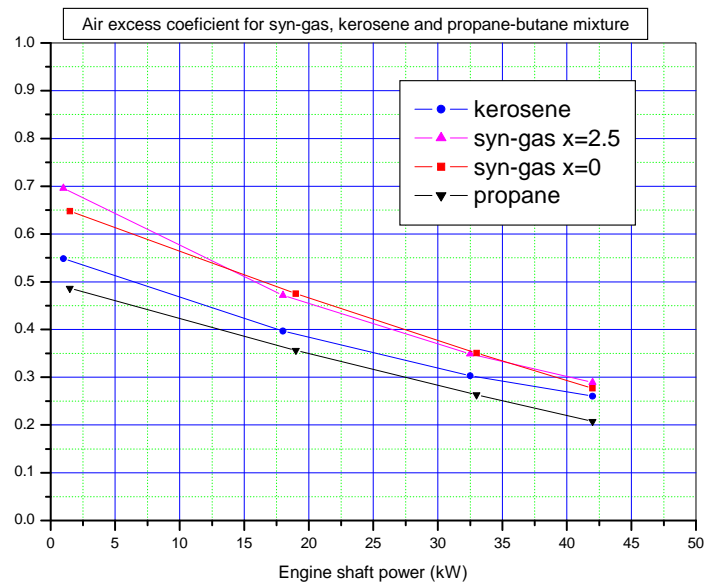

Figure 10. Coefficient of air excess in atomizer for different fuels

\section{ENGINE TEST WITH SYNGAS}

Engine tests were done at the site of Pyromex company in Munich, Germany. Engine control unit and measuring equipment were adjusted for such demonstration [13].

Control unit has clear logic: starting and driving to idle were exactly the same as for pure liquid fuel. Control unit is controlling engine rpm by adjusting electric fuel pump voltage. In transition to work with syngas control is starting to open gas valve while maintaining engine constant rpm by decreasing liquid fuel flow. At certain moment control would not be able to maintain constant rpm by decreasing liquid fuel which is signal to start to control engine rpm by gas control valve while completely stopping liquid fuel. Further operation is controlled only by gas control valve. Measured values were engine rpm, liquid fuel flow, syngas flow, exit temperature, fuel pump control voltage and gas valve control signal. Control unit was writing data for engine rpm, fuel pump control voltage and gas control valve signal, while other values were read from flowmeters and displays. Gasoline is used as a liquid fuel, while turbo oil grade 32 was used to lubricate and cool bearings and gearbox.

Test procedure was as follows:

1. Starter is accelerating the engine approximately at $17500 \mathrm{rpm}$.

2. Spark plug on.

3. Gasoline on.

4. Engine is accelerated to $37200 \mathrm{rpm}$ on gasoline.

5. Spark plug and starter off at $25000 \mathrm{rpm}$.

6. After 10 seconds at $37200 \mathrm{rpm}$ automatic control is starting to open synthetic gas valve while maintaining constant rpm of 37200 by decreasing gasoline flow.

7. In such a process when rpm starts to increase automatic control is closing gasoline valve and engine will continue to run only on gas at 39000 rpm. 
8. After about 20 seconds control is accelerating engine to the $42000 \mathrm{rpm}$ and keeps constant rpm.

9. Electric heaters of $2.5 \mathrm{~kW}, 3.5 \mathrm{~kW}$ and $8 \mathrm{~kW}$ were manually turned on and off while automatic control is maintaining constant rpm of $42000 \mathrm{rpm}$. Because gas is supplied from gas tank of $5 \mathrm{~m}^{3}$ volume under initial pressure of 7 bars during the test the pressure is decreasing and control at the end of the test is not able to keep 42000 but $40000 \mathrm{rpm}$ (valve is completely open).

10. Gas valve turned off.

11. Engine stopped.

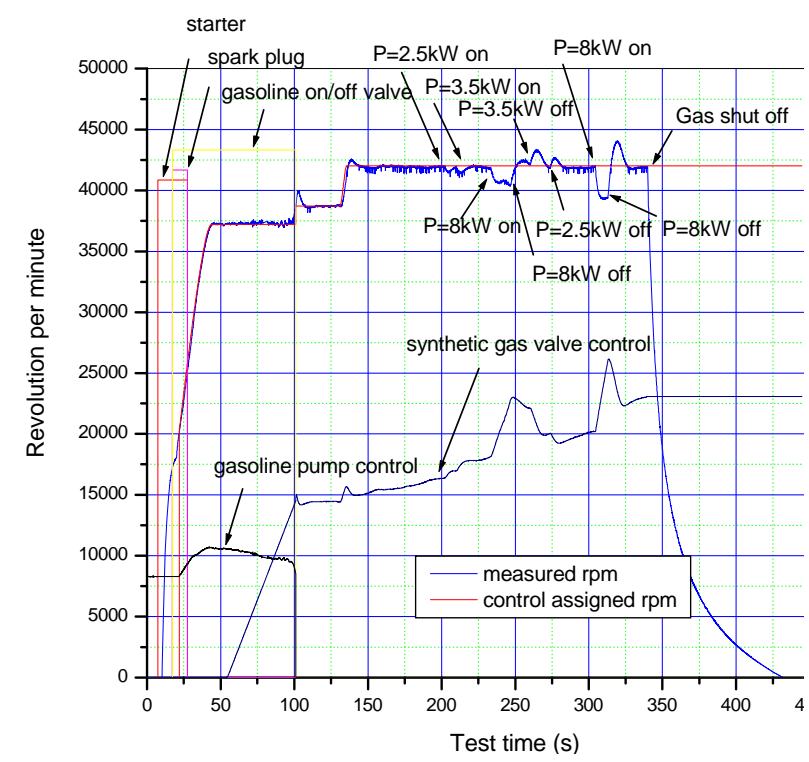

Figure 11. Engine test graph

Table 2. Comparison of fuel flows with power for 42000rpm

\begin{tabular}{|c|c|c|c|c|}
\hline$/$ & $\begin{array}{c}\mathrm{m}_{\text {air }} \\
(\mathrm{g} / \mathrm{s})\end{array}$ & $\begin{array}{c}\mathrm{m}_{\text {gasoline }} \\
(\mathrm{g} / \mathrm{s})\end{array}$ & $\begin{array}{c}\mathrm{m}_{\text {syn }} \\
(\mathrm{g} / \mathrm{s})\end{array}$ & $\begin{array}{c}\text { Tex }(\mathrm{K}) \\
\text { Gasoline/syngas }\end{array}$ \\
\hline Idle & 480 & 4.6 & 11.5 & $690 / 650$ \\
\hline Power $14 \mathrm{~kW}$ & 440 & 6.6 & 16.5 & $840 / 820$ \\
\hline
\end{tabular}

Air flow, gasoline flow rate and exit temperature for gasoline data in table 2 are from previously measured engine data, while syngas data are from performed tests.

\subsection{Result comments}

-Acording to figure 10 air flow is decreasing from 3.75 to $2.82 \mathrm{~g} / \mathrm{s}$ per atomizer when syn-gas is injection from 0 to full power flow i.e. atomizer is naturally adjusting equivalence ratio by giving $33 \%$ of required $44 \%$ to have the same as with kerosene. Differences are bigger at idle but combustion chamber and engine do not show any instability or efficiency problem.

-Very small difference is made by changing the position of gas injector about 5\% i.e. the choice will be according to assembling requirements.

-When considering the atomizer equivalence ratio for syn-gas and kerosene from $18 \%$ difference at iddle practically there is no difference at full power. It is interesting to make comparison with propane or similar gas as methane: in that case mixture is reacher then with kerosene $7 \%$ at iddle and $20 \%$ at full power.

-Engine test fuel flow rates shows a bit smaller efficiency of combustion chamber with syn-gas because sun-gas flow is bigger by $0.69 \%$ for the same thermal power, while total engine flow rate is bigger by $1.4 \%$ for iddle and $2.2 \%$ for $14 \mathrm{~kW}$. So, efficiency was lower by $2 \%$ and $2.9 \%$, for iddle and $14 \mathrm{~kW}$ operation respectively. The reason for that is probably higher level of velocities in the primary zone.

\section{CONCLUSION}

Main conclusions and contributions which can be taken from this work are:

-It was shown that this type of combustion chamber and atomizer are very suitable for application with synthetic gas or with dual liquid and gaseous fuel operation.

-Measured exit temperatures whre practically the same as with kerosene (table 2), which means for such composition that no special materials should be used. It should be noted that such statement is consequence of shifted temperature/coefficient of air excess curve from figure 4: air flow rate is considered the same in case of syngas and kerosene, syngas flow rate is bigger 43.2/17.4 times because of lower heating value while stochiometric ratio of syngas to kerosene stands as 4.15/14.77; as a result syngas engine operation will always be 1.44 times leaner than with kerosene, compensating higher adiabatic temperatures of air/syngas mixture.

-The test was using pressurized gas mixture. In real conditions gas mixture, which is typically comes at atmospheric pressure, must be pressurized and that will decrease overall system efficiency. Engine used for demonstration is of low pressure ratio 2.75 which affects thermodynamic efficiency but in application with such gases low pressure ratio is more than welcome because power for gas pressurization should be taken into account for overall efficiency.

-If the full power was required probably small modification of turbine stator would be required in order to pass bigger amount of gas but it does not change importance of presented demonstration. This statement depends on compressor map in terms of surging and it was not of primary importance for this research.

-Practically there are not so many gas-turbines operating with synthetic gases, especially small gasturbines [14]. The main reason is that engineers are always trying to adopt existing engine designed for use with liquid fuel what sometimes is not possible. Usually high compressor pressure ratio or combustion chamber with classical arrangement is the main reasons. If so, syngas pressurization or completely new combustion chamber must be considered, causing undesired expenses. Another logic reason is of commercial type: big companies [15], [16] do not have clear commercial reason to enter into such a field giving opportunity to smaller more elastic companies to grab the part of this market. 


\section{REFERENCES}

[1] Jojić, B., Milosavljević, V., Blagojević, Đ., Fotev V. and Milojković, P..: Glavni projekat motora TM 40, Beograd 1984.

[2] Dini, D.: Modification of fuel control system of gas turbine engine from kerosene to hydrogen, RTOAVT symposium, Lisbon, Portugal, October 12-16. 1998.

[3] Johnson M.S.: Prediction of gas-turbine on- and off-design performance when firing on coal-derived syngas, Transactions of ASME, Vol. 114, April 1992.

[4] Wu, J., Brown, P., Diakhunchak, I., Gulati, A., Lenze, M. and Koestlin B.: Advanced gas turbine combustion system for high hydrogen fuels, Proceedings of GT2007, ASME turbo expo 2007., Montreal, Canada, 2007.

[5] Zhang, J., Ma, L., Li, Z. and Ni, W.: Modeling an air-cooled gas turbine of the integrated gasification combined cycle in Aspen plus, International conference on future electrical power and energy systems, IERI, 2012.

[6] Singh, D., Nishiie T., Tanvir S. and Qiao L.:An experimental and kinetic study of syngas/air combustion at elevated temperatures and the effect of water addition, Fuel 94 pp. 448-456, 2012.

[7] Daniele, S., Jansohn, P. and Boulouchos, K.: Experimental Investigation of Lean Premixed Syngas Combustion at Gas Turbine Relevant Conditions: Lean Blow Out Limits, Emissions and Turbulent Flame Speed, Combustion Colloquia 32nd Meeting on Combustion, 2009.

[8] Zhang, Q., Noble, R.D: Lieuwen T.: Blowout Measurements in a Syngas-Fired Gas Turbine Combustor, The $22^{\text {nd }}$ Annual International Pittsburgh Coal Conference, September 12-15, 2005.

[9] Walton, S.M., He, X., Zigler, B.T. and Wooldridge M.S.: An experimental investigation of the ignition properties of hydrogen and carbon monoxide mixtures for syngas turbine applications, Proceedings of the Combustion Institute 31 pp.3147-3154, 2007.

[10] Tabatabaei, A.F. and Soroudi, M.A.: A kinetic study of syngas combustion characteristics for gas turbine applications, MCS 7, Cagliari, Italy, September 11-15., 2011.

[11] Adžić M.: Effects of changes jet fuel quality on gas turbine performance and emissions, Fuels and lubricants, Vol 28, No 5-6, pp.233-244, 1989.

[12] Davidović, N.: Mathematical model of turbojet engine combustion chamber primary zone, FME Transactions (2007) 35 pp.29-34, Belgrade, Serbia, 2007.

[13] Popesku, J., Stanciu, V., Vilag, V. and Cuciumita, C.: Experimental setup for gas turbines operating on alternative gas fuels, U.P.B. Sci. Bull., Series D, Vol. 75, Iss. 3, Romania, 2013.
[14] Biomas engineering Ltd.: Development of microturbine plant to run on gasifier producer gas, Contract number B/U1/00762/REP, 2004.

[15] GE energy: Syngas fuel technology, General Electric, 2010.

[16] Poloczek, V. and Hermsmeyer, H.: Modern gas turbines with high fuel flexibility, Power-gen Asia, Kuala Lumpur, Malaysia, October 21-23, 2008.

\section{NOMENCLATURE}

$H_{m} \quad$ Mixture heating value (MJ/kg)

$H_{H 2} \quad$ Hydrogen heating value (MJ/kg)

$H_{C O} \quad$ Carbon monoxide heating value $(\mathrm{MJ} / \mathrm{kg})$

$M_{H 2} \quad$ Hydrogen molecular mass $(\mathrm{kg} / \mathrm{kmol})$

$M_{C O}$ Carbon monoxide molecular mass $(\mathrm{kg} / \mathrm{kmol})$

$m_{k e r} \quad$ Kerosene mass flow rate $(\mathrm{g} / \mathrm{s})$

$m_{\text {syn }} \quad$ Syn-gas mass flow rate (g/s)

$P \quad$ Pressure $(\mathrm{Pa})$

$P M_{H 2} \quad$ Mass fraction of hydrogen

$P M_{C O}$ Mass fraction of carbon monoxide

$R_{u} \quad$ Universal gas constant $8314 \mathrm{~J} / \mathrm{kgK}$

$R_{m} \quad$ Mixture gas constant (J/kgK)

$R_{H 2} \quad$ Hydrogen gas constant $(\mathrm{J} / \mathrm{kgK})$

$R_{C O} \quad$ Carbon monoxide gas constant (J/kgK)

$T$ Temperature (K)

$V \quad$ Volume $\left(\mathrm{m}^{3}\right)$

$\rho_{\mathrm{H} 2} \quad$ Hydrogen density

$\rho_{\mathrm{CO}} \quad$ Carbon monoxide density

$\varphi \quad$ Equivalence ratio

\section{МОДИФИКАЦИЈА ПОСТОЈЕТЕГ ТУРБОВРАТИЛНОГ МОТОРА ДА БИ КАО ГОРИВО КОРИСТИО СИНТЕТИЧКИ ГАС}

Никола Давидовић, Предраг Милош, Aiman Elmahmodi, Марко Милош, Бранислав Јојић, Ивана Тодић

Синтетички гас је данас ко-производ процеса као што су гасификација отпада и прераде биомасе, угља и других потенцијалних горива. Иако састав синтетичког гаса зависи од претходних процеса, генерално се састоји од мешавине водоника, угљенмоноксида и метана у различитим односима. Идеја да се синтетички гас добијен прерадом отпада користи као гориво за турбо-генератор је веома привлачна, али и врло захтевна. У овом раду је презентована модификација постојећег турбовратилног мотора да би могао да користи синтетички гас као гориво. Поред проблема као што су мала топлотна моћ, другачији стехиометријски однос у поређењу са керозином и висок проценат водоника, инжењерски задатак је био да се проблем реши са минималним бројем измена. Проблем је решен модификациојом постојећих ваздушних распршивача и верификован је експериментално. 